\title{
CYCLIC FLEXURAL BEHAVIOR OF POLYPROPYLENE AND SISAL FIBER REINFORCED CONCRETE
}

\author{
$\underline{\text { Raylane de Souza Castoldi }} \underset{2}{(1)}$ Lourdes Maria Silva de Souza ${ }^{(1)}$ and Flávio de Andrade \\ Silva $^{(1)}$
}

(1) Department of Civil and Environmental Engineering, Pontifícia Universidade Católica do Rio de Janeiro, Brazil

https://doi.org/10.21452/bccm4.2018.02.10

\begin{abstract}
This experimental research investigation aims to compare the cyclic behavior of concrete reinforced with discrete polypropylene and sisal fibers. Prismatic concrete specimens having dimensions of $550 \times 150 \times 150$ mm were produced with concrete containing low alkaline content. Both fibers used were $51 \mathrm{~mm}$ long and were incorporated into fractions of $6 \mathrm{~kg} / \mathrm{m}^{3}$ and $10 \mathrm{~kg} / \mathrm{m}^{3}$ of polypropylene and sisal fiber, respectively. A cyclic three-point flexural test was conducted in notched beams based on recommendations of RILEM TC 89-FMT. All the composites presented deflection softening behavior and both fibers provided the same level of residual loads. The loading and unloading cycles resulted in degradation of stiffness with increasing CMOD, being more evident for concretes reinforced with polypropylene fiber. Some fracture parameters obtained from the cyclic tests showed that both composites presented similar fracture properties.
\end{abstract}

\section{INTRODUCTION}

Concrete is one of the most widely used materials in construction mainly due to the various advantages of this material, which includes high mechanical strength, easy production and molding, with relatively low cost [1]. However, concrete presents some limitations, such as low deformation capacity and the rapid propagation of cracks when subjected to tensile stresses, being considered a fragile material [1,2]. An alternative to minimize this limitation is the use of dispersed fibers into the cementitious matrix. The incorporation of fibers results in higher flexural toughness, fatigue resistance and impact strength. In addition, fiber reinforced concretes become more efficient after the formation of the first crack [3]. Fibers act as a bridge to transfer the stress in the region of a crack, increasing the energy absorption capacity of the material and reducing the propagation and expansion of the existing cracks [2,3].

There are several types of fibers available, produced by different materials and shapes. Despite the possibility of use in the form of textiles, the use of randomly dispersed fibers in the matrix has been more evident for economic reasons [4]. Nowadays, the most used fibers as concrete reinforcement are the steel and polypropylene fibers. However, the polymeric fibers present some advantages such as the chemical resistance and the higher durability in 
cementitious matrices [2]. Currently, they are widely used for floor and pavements applications, sprayed concrete and precast elements [2,5].

Some fibers from natural resources, such as sisal fiber, appear as an alternative to synthetic fibers. Natural fibers exist in abundance and have their use encouraged by being renewable, biodegradable and with high availability at low cost [2]. However, the low durability of this type of fiber in alkaline environment is still a barrier to its use in a large scale and the use of these fibers as discrete reinforcement in the concrete is still little studied [6]. Therefore, the evaluation of the application of this type of fiber is important to encourage their use and make them competitive in relation to synthetic fibers.

In order to evaluate the influence of the presence of dispersed fibers in the cementitous matrix, is common to use some method for measure the composite tensile stress-strain response. Although the uniaxial tensile test is the most appropriate, there are some complications due to the configuration of this test. There is the possibility of stress accumulation in the specimen clamping on the test arrangement and the specimen geometry can influence the results obtained. For these reasons, flexural tests have become an alternative to evaluate these composites [7].

Most studies of fiber reinforced concrete investigate the flexural behavior under monotonic loading instead evaluate under cyclic loading [8]. The RILEM TC 89-FMT [9] committee recommends flexural tests on notched prismatic specimens submitted to loading and unloading cycles. By the relation between load and crack mouth opening displacement (load-CMOD curve), some experimental parameters of the cycles can be obtained: the load at the beginning of each cycle, the residual CMOD value, the initial compliance $\left(\mathrm{C}_{\mathrm{i}}\right)$ and the compliance at each cycle $\left(\mathrm{C}_{\mathrm{u}}\right)$. From this procedure, it is possible to measure some fracture parameters that are sufficient to characterize the fracture resistance and energy dissipation of the composite $[7,9]$. Moreover, previous researches have shown that the compliance variation at each cycle performed represents the dissipation of energy with the development of crack the during loading $[8,10,11]$.

The studies on determining the fracture parameters of cementitious materials initiated by Kaplan in 1961 [12,13]. At this time, he applied the principles of classical linear elastic fracture mechanism (LEFM) [14], in which a single fracture parameter is used to characterize the composite. In the 1970s, experimental investigations indicated that LEFM was no longer valid for quasi-brittle materials such as concrete [7,14-16]. Consequently, several models were proposed to describe the concrete failure, such as the fictitious crack model [17], the crack band model [18], the two-parameter model [19], the effective crack model [20], among others. In these cases it is necessary at least two fracture parameters to characterize the composite. The RILEM TC 89-FMT [9] recommendation is based on the two-parameter model, which two parameters may be determinate from three-point flexural tests on notched beams: the critical stress intensity factor $K_{I C}$ and the critical crack tip opening displacement $C T O D_{C}$.

The main objective of this work is to investigate experimentally the flexural behavior of polypropylene and sisal fiber reinforced concrete under cyclic loading and compare the mechanical behavior of these composites. The test methodology adopted was similar to the recommendations of RILEM TC 89-FMT [9] conducting cyclic three-point flexural tests in notched beams.

\section{MATERIALS AND SPECIMEN PREPARATION}

\subsection{Fibers}

The sisal fibers were extracted from Agave sisalana plant by a decortication process. The fibers were obtained in a farm located in the city of Valente, state of Bahia, Brazil. After receiving the sisal fibers in bundles of long fibers, it was necessary a preliminary procedure to 
remove all the impurities. This procedure consisted in submerging the fibers in water at $70 \pm$ $5^{\circ} \mathrm{C}$ for approximately one hour. After, the fibers were air-dried for 48 hours and finally cut manually into segments of $51 \mathrm{~mm}$ length. On the other hand, the polypropylene fiber was received ready for use as reinforcement. These fibers presented twisted geometry, which result in improvement on the mechanical anchorage with the matrix. The main physical and mechanical characteristics of these fibers obtained in laboratory are shown in Table 1.

Table 1: Fibers properties. Standard deviation values are presented in parenthesis.

\begin{tabular}{ccc}
\hline Properties & Polypropylene fiber & Sisal fiber \\
\hline Length $(\mathrm{mm})$ & 51 & 51 \\
Cross-sectional area $\left(\mathrm{mm}^{2}\right)$ & $0.63(0.13)$ & $0.03(0.01)$ \\
Aspect ratio & $57.77(6.07)$ & $269.67(39.26)$ \\
Tensile strength $(\mathrm{MPa})$ & $260.72(13.15)$ & $383.88(49.88)$ \\
Elastic modulus $(\mathrm{GPa})$ & $2.29(0.56)$ & $8.77(3.53)$ \\
\hline
\end{tabular}

\subsection{Matrix}

The concrete matrix was an adaptation of a mix ratio proposed by Marangon [21]. In order to obtain a low alkaline matrix to minimize the degradation process of sisal fibers, $50 \%$ by mass of Portland cement was replaced by $30 \%$ of metakaolin and $20 \%$ of fly ash. The cementitous materials used in the concrete production were Brazilian cement type CP II F-32, fly ash, metakaolin, silica fume and silica flour (quartz powder). Fine aggregates of two classes of particle size were used: one ranging from 0.15 to $0.85 \mathrm{~mm}$ (S1) and the other ranging from $0.85 \mathrm{~mm}$ to $4.8 \mathrm{~mm}$ (S2). Coarse aggregate with maximum diameter of $12.5 \mathrm{~mm}$ and superplasticizer were also included on the mix. The resulting water/cement ratio was 0.5 . The concrete compressive strength after 28 days was $57.0 \pm 21.05 \mathrm{MPa}$ and the slump spreading was $479 \pm 2 \mathrm{~mm}$. The concrete composition is given in Table 2 .

Table 2: Proportions on concrete composition. All values in $\mathrm{kg} / \mathrm{m}^{3}$.

\begin{tabular}{|c|c|c|c|c|c|c|c|c|c|}
\hline \multirow[t]{2}{*}{$\begin{array}{c}\text { Coarse } \\
\text { Aggregate }\end{array}$} & \multicolumn{2}{|c|}{$\begin{array}{c}\text { Fine } \\
\text { Aggregate }\end{array}$} & \multirow[t]{2}{*}{ Cement } & \multirow[t]{2}{*}{$\begin{array}{l}\text { Fly } \\
\text { Ash }\end{array}$} & \multirow[t]{2}{*}{ Metakaolin } & \multirow[t]{2}{*}{$\begin{array}{l}\text { Silica } \\
\text { Fume }\end{array}$} & \multirow[t]{2}{*}{$\begin{array}{l}\text { Silica } \\
\text { Flour }\end{array}$} & \multirow[t]{2}{*}{ Water } & \multirow{2}{*}{$\begin{array}{c}\text { Super- } \\
\text { plasticizer }\end{array}$} \\
\hline & S1 & S2 & & & & & & & \\
\hline 492.0 & 826.7 & 99.6 & 180.0 & 224.0 & 94.8 & 45.0 & 70.0 & 155.7 & 21.6 \\
\hline
\end{tabular}

\subsection{Preparation of samples}

Two different composites were produced: the composite CPP6, which the reinforcement was $6 \mathrm{~kg} / \mathrm{m}^{3}$ of polypropylene fiber and the composite CSI10, with $10 \mathrm{~kg} / \mathrm{m}^{3}$ of sisal fiber as reinforcement. For each mixture, three composites were made. The specimens for the flexural tests were prismatic, with dimensions of $550 \times 150 \times 150 \mathrm{~mm}$. Notches with $25 \mathrm{~mm}$ long centered on the bottom side of the prisms were made using a $3 \mathrm{~mm}$ thick diamond saw. The specimens were cured for 28 days at room temperature of $24.4^{\circ} \mathrm{C}$ and $65.7 \%$ of humidity before testing.

\section{TESTING METHODS}

The cyclic flexural tests were performed based on the recommendations of RILEM TC 89FMT [9]. Three-point flexural tests were carried by using a MTS servo-controlled hydraulic testing machine with a closed loop type of control and a load cell of $100 \mathrm{kN}$. The span between 
the support rollers was $500 \mathrm{~mm}$. The superior roller for load application was fixed on the specimen midspan. The three rollers had a diameter of $37 \mathrm{~mm}$. One clip gage fixed on the notch was used for the measurement of the crack mouth opening displacement (CMOD). The details of the setup are presented in Figure 1.

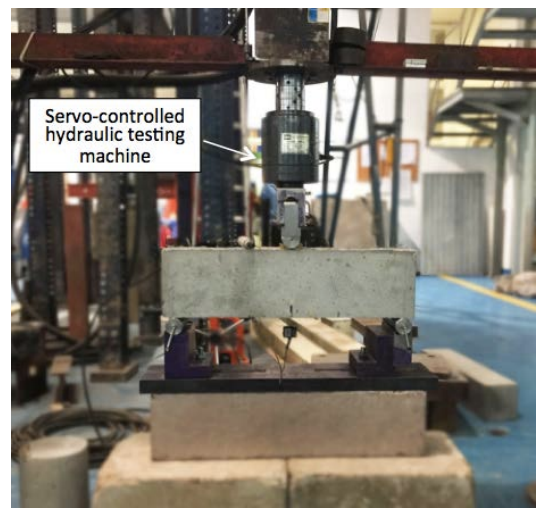

(a)

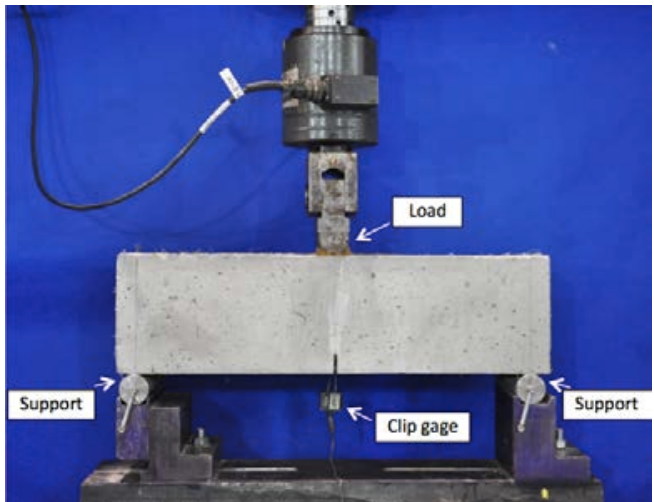

(b)

Figure 1: (a) Servo-controlled hydraulic testing machine used in the test and (b) the three-point flexural test setup in detail.

The loading procedure was controlled by the CMOD. Up to CMOD equal to $0.18 \mathrm{~mm}$, the loading rate was $0.05 \mathrm{~mm} / \mathrm{min}$. After $0.18 \mathrm{~mm}$, the loading rate was $0.2 \mathrm{~mm} / \mathrm{min}$ until reach CMOD equal to $1 \mathrm{~mm}$, which was the end of the test. The unloading procedure was controlled by the load. The unloading was executed at pre-defined CMOD levels $(0.02,0.04,0.06,0.10$, $0.14,0.18,0.30$ and 0.50 ) with the load rate of $8 \mathrm{kN} / \mathrm{m}$ for all unloading performed. The loading and unloading procedure and the specimen geometry is shown in Figures 2a and 2c, respectively.

The elastic modulus (E) is calculated from the Eq. 2, in which the parameter $C_{i}$ is defined as the initial compliance shown in Figure 2.b. In addition, $V(\alpha)$ is obtained from the Eq. 3, where $\alpha_{0}$ is the normalized notch length, defined as $a_{0} / d$.

$$
\begin{aligned}
& E=\frac{6 S a_{0} V\left(\alpha_{0}\right)}{C_{i} d^{2} t} \\
& V(\alpha)=0.76-2.28 \alpha+3.87 \alpha^{2}-2.04 \alpha^{3}+\frac{0.66}{(1-\alpha)^{2}}
\end{aligned}
$$
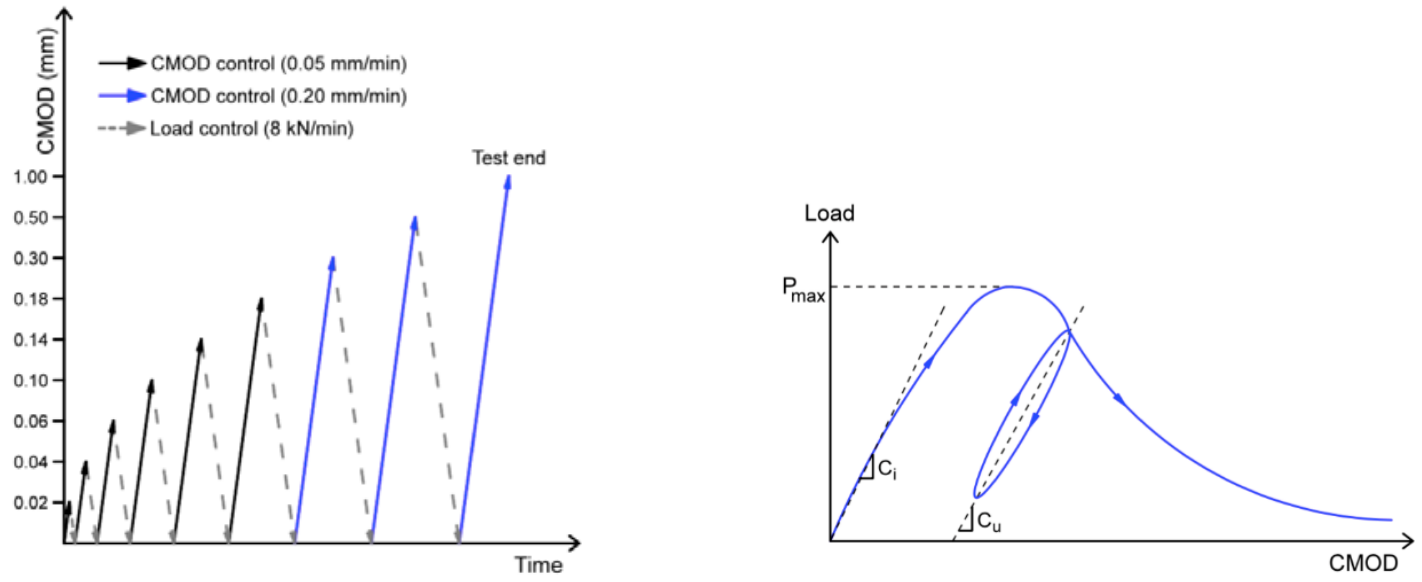
(a)

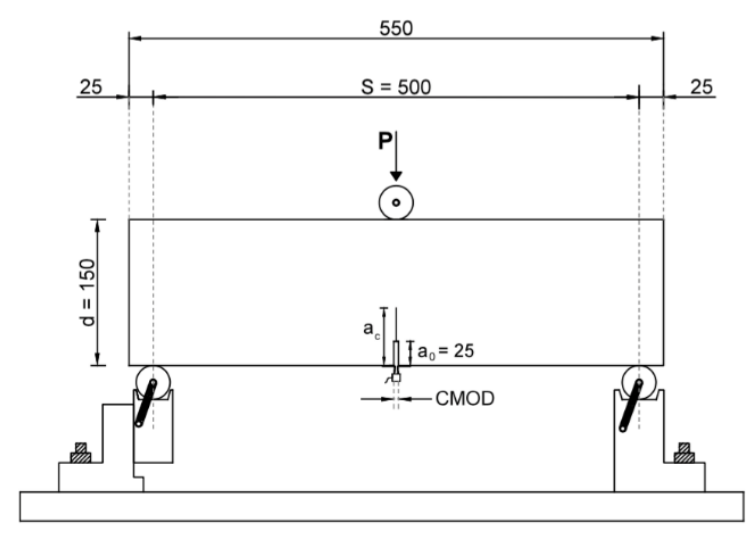

(b)

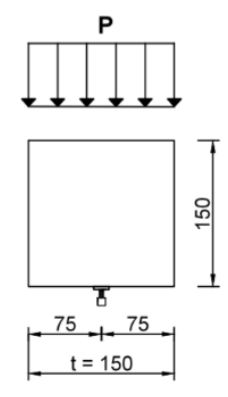

(c)

Figure 2: (a) Cyclic loading and unloading procedure, (b) a typical load-CMOD response with some experimental parameters and (c) the testing configuration and geometry of specimen.

All dimensions in mm.

The critical crack length $a_{c}$ is the crack length at which the crack becomes unstable [10]. This parameter is obtained by the Eq. 4 by an iterative process and can be used to determine the crack length at any cycle. The term $C_{u}$ is the compliance corresponding to the unloading cycle and the normalized critical crack length $\alpha_{c}$ is defined as $a_{c} / d$. In addition, the critical stress intensity factor $\left(K_{I C}\right)$ is obtained from Eq. 6. This parameter is defined as the stress intensity factor obtained at the critical effective crack tip, using the measured maximum load [9].

$$
\begin{aligned}
& a_{c}=\frac{E C_{u} d^{2} t}{6 S V\left(\alpha_{c}\right)} \\
& K_{I C}=3 P_{\max } \frac{S \sqrt{\left(\pi \alpha_{c}\right)} F\left(\alpha_{c}\right)}{2 d^{2} t} \\
& F\left(\alpha_{c}\right)=\frac{1.99-\alpha_{c}\left(1-\alpha_{c}\right)\left(2.15-3.93 \alpha_{c}+2.7 \alpha_{c}{ }^{2}\right)}{\sqrt{\pi}\left(1+2 \alpha_{c}\right)\left(1-\alpha_{c}\right)^{3 / 2}}
\end{aligned}
$$

The critical crack tip opening displacement $\left(C T O D_{c}\right)$, obtained from Eq. 7, is defined as the $C T O D$ calculated at the original notch tip of the specimen, using the measured maximum load and the critical effective crack length [9]. The critical intrinsic fracture toughness $\left(G_{I C}\right)$ is the critical level of toughness against crack initiation [7], and is obtained from Eq. 8. The term $\beta_{0}$ is equivalent to the relation $a_{c} / a_{0}$.

$$
\begin{aligned}
& C T O D_{c}=\frac{6 P_{\max } S a_{c} V\left(\alpha_{c}\right)}{E d^{2} t} \sqrt{\left(1-\beta_{0}\right)^{2}+\left(1.081-1.149 \alpha_{c}\right)\left(\beta_{0}-\beta_{0}{ }^{2}\right)} \\
& G_{I C}=\frac{K_{I C}{ }^{2}}{E}
\end{aligned}
$$

\section{RESULTS AND DISCUSSION}

The load-CMOD curves presented at Figures $3 \mathrm{a}$ and $3 \mathrm{~b}$ report the flexural responses obtained for the composite CPP6 and CSI10, respectively. Each curve corresponds to one 
specimen tested, named S1, S2 and S3. Figure 3c shows the mean curves for the composites CPP6 and CSI10, for comparison. It was observed that all the composites presented linear behavior until the appearance of the first crack, followed by a decrease in load with the increase of the CMOD. This behavior is named deflection softening, and is characterized by the appearance of a single crack, common in composites reinforced with discrete fibers [22-24]. Although the pre-cracking behavior was similar for both composites, the post-cracking behavior varied according to the fiber type.

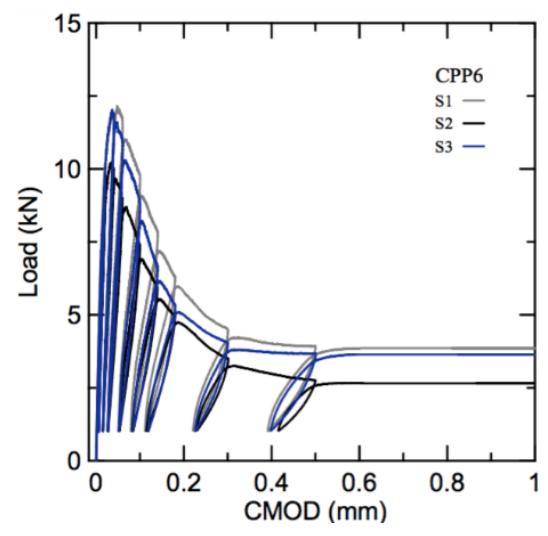

(a)

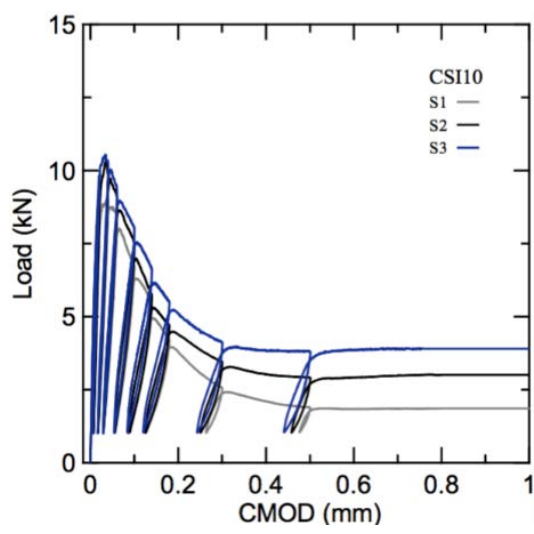

(b)

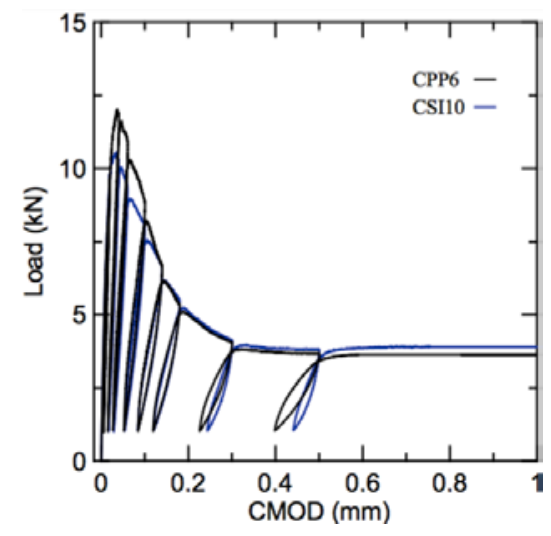

(c)

Figure 3: Results from cyclic three-point flexural tests for (a) CPP6 and (b) CSI10 composites. (c) Representative curve for each composite.

The loading and unloading curves of all concretes tested did not coincide and were not parallel to the initial slope. The slope was inversely proportional to the crack mouth opening displacement. The larger the CMOD, smaller the slope $[7,8,10,11]$. This fact indicates that there is a degradation of stiffness, which is related to energy dissipation during the loading and unloading process [8]. With the increasing of the load, the cracks develop and the damages are gradually accumulated, while the stiffness decreases. From Figure 3c it is possible to notice that the slope decrease was more evident for the composite CPP6. Even though loading levels were similar for both composites, the lower amount of polypropylene fibers resulted in higher loss of stiffness with the crack development, mainly for CMOD equal to $4 \mathrm{~mm}$.

The change in compliance and inelastic deformation at each loading and unloading cycle are indicators of crack increase and were used to calculate parameters of fracture mechanics $[9,10]$, presented in Table 3. The similar values for modulus of rupture means that both composites presented the same tensile strength. Due to the low amount of fibers incorporated into the matrix, the tensile strength of the composite may be associated with the plain concrete tensile strength, and the fibers only act on the load absorption in the post-cracking region.

Other parameters such as modulus of elasticity, critical effective crack length, critical intensity factor and $C T O D_{c}$ did not presented considered discrepancy between the two evaluated composites. The difference observed in the critical strain energy release rate may be associated with the distribution of fibers on the cracked section, which can present variation due to the difficult in disperse the fibers on the mixture process of the samples.

Table 3: Summary of cyclic frature parameters. Standard deviation values are presented in parentheses.

\begin{tabular}{ccc}
\hline Parameters & CPP6 & CSI10 \\
\hline Number of cycles & 8 & 8
\end{tabular}




$\begin{array}{ccc}\text { Apparent MOR }(\mathrm{MPa}) & 3.7(0.3) & 3.2(0.3) \\ \text { Elastic modulus }(\mathrm{GPa}) & 19.6(1.5) & 20.2(0.9) \\ \text { Critical crack length } a_{c}(\mathrm{~mm}) & 41.3(4.3) & 41.0(2.0) \\ \text { Critical stress intensity factor } K_{I C}\left(\mathrm{MPa} . \mathrm{mm}^{0.5}\right) & 30.1(3.9) & 25.9(0.9) \\ \text { Critical CTOD }(\mu \mathrm{m}) & 20.9(5.1) & 17.0(0.9) \\ \text { Critical strain energy release rate } G_{I C}(\mathrm{~N} / \mathrm{mm}) & 46.7(9.8) & 33.2(3.8)\end{array}$

\section{CONCLUSIONS}

After the cracking of the matrix, both fibers guaranteed the deflection softening behavior to the cementitious matrix. It was observed that sisal fiber could provide the same level of residual strength as the polypropylene fiber, considering superior dosage of sisal fiber. It was possible to verify from the load-CMOD curves that the concrete reinforced with polypropylene fiber presented higher degradation of the stiffness, evidenced by the higher reduction of the cycles slopes with the development of the crack. However, is important to highlight that this may have happened due to the less amount of polypropylene fiber in the cracked section and it is not necessary associated with the fiber properties used for reinforcement. The fracture parameters obtained for the three flexural tests show that both composites presented similar values for most of the parameters.

After evaluation of the cyclic behavior and fracture parameters obtained from the composites, it can be concluded that sisal fibers can successfully be used as concrete reinforcement, considering the need of higher dosage of sisal fiber than polypropylene fiber.

\section{REFERENCES}

[1] MEHTA, P. K.; MONTEIRO, P. J. M. Concrete: Microstructure, Properties and Materials. 3.ed. McGrawHill, 2006.

[2] BENTUR, A.; MINDESS, S. Fibre Reinforced Cementitious Composites. 2.ed. Taylor \& Francis, 2007.

[3] NAAMAN, A. E.; REINHARDT, H. W. Proposed classification of HPFRC composites based on their tensile response. Mater Struct, vol. 39, no. 289, pp. 547-555, 2006.

[4] PEREIRA, E. V. Influência de Fibras de Aço no Comportamento Mecânico e nos Mecanismos de Fissuração de Concretos Autoadensáveis. Rio de Janeiro, 2017. Dissertação de Mestrado - Departamento de Engenharia Civil e Ambiental, Pontifícia Universidade Católica.

[5] FIGUEIREDO, A. D. Concreto Reforçado Com Fibras. São Paulo, 2011. Livre Docência - Escola Politécnica, Universidade de São Paulo.

[6] BERGSTROM, S. G.; GRAM, H. Durability of alkali-sensitive fibres in concrete. Int J Cem Comp Light Concr, vol. 6, no. 2, pp. 75- 80, 1984.

[7] MOBASHER, B.; BONAKDAR, A.; BAKHSHI, M. Back-calculation procedure for cyclic flexural fracture tests in fiber reinforced concrete. Fract Mech Appl Concr - ACI Technical Publication, SP-300. January, 2015.

[8] BOULEKBACHE, B.; HAMRAT, M.; CHEMROUK, M.; AMZIANE, S. Flexural behaviour of steel fibrereinforced concrete under cyclic loading. Constr Build Mater, vol. 126, pp. 253-262, 2016.

[9] RILEM TECHNICAL COMMITTEES. RILEM TC 89-FMT: Fracture mechanics of concrete Determination of fracture parameters of plain concrete using three-point bend tests. United States, 1991.

[10] DEY, V.; KACHALA, R.; BONAKDARR, A.; MOBASHER, B. Mechanical properties of micro and submicron wollastonite fibers in cementitious composites. Constr Build Mater, vol. 82, no. April, pp. 351-359, 2015.

[11] HAMAD, W. I.; OWEN, J. S.; HUSSEIN, M. F. M. An efficient approach of modelling the flexural cracking behaviour of un-notched plain concrete prisms subject to monotonic and cyclic loading. Eng Struct, vol. 51, pp. 36-50, 2013.

[12] OHTSU, M. Crack propagation in concrete: linear elastic fracture mechanics and boundary element method. Theor Appl Fract Mech, vol. 9, pp. 55-60, 1988.

[13] KAPLAN, M. Crack propagation and the fracture of concrete. ACI J Proc, vol. 58, pp. 591-610, 1961.

[14] INCE, R.; ALYAMAÇ, K. Determination of fracture parameters of concrete based on water-cement ratio. 
Indian J Eng Mater Sci, vol. 15, pp. 14-22, 2008.

[15] CHENGSHENG, O.; BARZIN, M.; SURENDRA, P. An r-curve approach for fracture of quasi-brittle materials. Eng Fract Mech, vol. 37, pp. 901-13, 1990.

[16] KARIHALOO, B.; NALLATHAMBI, P. Effective crack Model for the determination of fracture toughness of concrete. Eng Fract Mech, vol. 35, pp. 637-45, 1990.

[17] HILLERBORG, A.; MODÉER, M.; PETERSSON, P. Analysis of crack formation and crack growth in concrete by means of fracture mechanics and finite elements. Cem Concr Res, vol. 6, pp. 773-81, 1976.

[18] BAZANT, Z.; OH, B. Crack band theory of concrete. Mater and Struct, vol. 16, pp. 155-77, 1983.

[19] JENQ, B.; SHAH, S. Two Parameter Fracture Model for Concrete. J Eng Mech, vol. 111, pp. 1227-41, 1986.

[20] NALLATHAMBI, P.; KARIHALOO, B. Prediction of load deflection behavior of plain concrete from fracture energy. Cem Concr Res, vol. 16, pp. 373-82, 1986.

[21] MARANGON, E. Desenvolvimento e caracterização de concretos auto- adensáveis reforçados com fibras de aço. Rio de Janeiro, 2006. Dissertação de Mestrado - COPPE, Universidade Federal do Rio de Janeiro.

[22] CIFUENTES, H.; GARCÍA, F.; MAESO, O.; MEDINA, F. Influence of the properties of polypropylene fibres on the fracture behaviour of low-, normal- and high-strength FRC. Constr Build Mater, vol. 45, pp. 130-137, 2013.

[23] LEE, J. H.; CHO, B.; CHOI, E.; KIM, Y. H. Experimental study of the reinforcement effect of macro-type high strength polypropylene on the flexural capacity of concrete. Constr Build Mater, vol. 126, pp. 967975, 2016

[24] SANTOS, F. M. R.; SOUZA, T. F.; BARQUETE, D. M.; AMADO, F. D. R. Comparative analysis of the sisal and piassava fibers as reinforcements in lightweight cementitious composites with EVA waste. Constr Build Mater, vol. 128, pp. 315-323, 2016. 